Island Studies Journal, Vol. 7, No.1, 2012, pp. 119-134

\title{
Trumping the Ethnic Card: How Tourism Entrepreneurs on Rodrigues tackled the 2008 Financial Crisis
}

\author{
Carsten Wergin \\ Social Policy Research Centre \\ The University of New South Wales \\ Sydney, Australia \\ c.wergin@unsw.edu.au
}

\begin{abstract}
The 2008 global financial crisis had significant repercussions on small island states and territories. This article discusses the efforts of tourism entrepreneurs from Rodrigues, a subnational island jurisdiction and a dependency of the Republic of Mauritius, to combat those effects by organizing themselves as the group Associations $d u$ Tourisme Réunies (ATR). Their aim was to secure subsidies from the Mauritian government to reduce the price of airfares to Rodrigues so as to attract more tourists to the island. The article offers an ethnographic account of how the economic crisis was tackled in a creative way by ATR and how its members put the negative image of a Creole minority suppressed by a Hindu majority to strategic use to achieve a stronger recognition of Rodriguan interests within the Republic of Mauritius.
\end{abstract}

Keywords: ethnicity; global financial crisis; islands; Mauritius; Rodrigues; tourism

(C) 2012 Institute of Island Studies, University of Prince Edward Island, Canada

\section{Introduction}

The 2008 financial crisis has had a strong impact all over the world; many consider it to be the most significant financial meltdown since the Great Depression of the 1930s. Small island states and territories dependent on tourism were particularly affected by its related significant decline in consumer wealth. With less money to spend, there were less people who could afford a holiday in remote destinations. Consequently, there were fewer tourists who travelled there. Mauritius is a particular case in point where tourism, together with the sugarcane and textile industries, is traditionally considered the third pillar of the economy (Aladin, 1993; Bunwaree, 2001; Dommen \& Dommen, 1999; Lincoln, 2006).

This article centres on an organization formed by tourism entrepreneurs from the small island of Rodrigues, a subnational island jurisdiction and a dependency of the Republic of Mauritius, called Associations du Tourisme Réunies (ATR). In order to tackle the problems triggered by the significant drop in visitor numbers due to the 2008 global financial crisis, ATR sought to secure subsidized airfares to attract more tourists to their island. I accompanied their representatives during their negotiation process with the Mauritian government. The analysis shows how the group made creative use of ethnic difference to achieve goals that went beyond mere financial support; namely a stronger recognition of Creole/Rodriguan interests and ethnic diversity within Mauritian society as a whole. For this, economic misfits and ethnic conflict between Mauritius and its small island dependency Rodrigues, in particular those affecting 


\section{Wergin}

people's mobilities, are analysed ethnographically (Tsing, 2000; Lash \& Urry, 1994; Neveling \& Wergin, 2009; Wynne, 2005).

The article discusses events on Rodrigues, using the ATR initiative to present the regional-toglobal interconnections of the island set out in the realms of tourism development and challenges faced by the 2008 global financial crisis. This includes the assessment of the wider interests of the ATR members as part of a well-educated Société Civil. Particular attention will be paid to the historical specificity of events surrounding the negotiations of Rodriguan tourism entrepreneurs with the Mauritian government, as well as to the alliances they formed to achieve their goals. This will construct a larger picture of current Rodriguan socio-cultural politics as a regional process with "open-ended indeterminacy" (Tsing, 2000: 349). But, before that, a historical overview of Rodrigues that includes its past and current political and sociocultural situation.

\section{Overview}

In 1528, the Portuguese sailor Diego Rodriguez discovered an island that was to bear his name: $109 \mathrm{~km}^{2}$ of volcanic land, almost entirely surrounded by a $90 \mathrm{~km}^{2}$ coral reef that has created a lagoon twice the size of the island. Its highest point is Mont Limon with an elevation of about $355 \mathrm{~m}$. Rodrigues is a hybrid cultural space. It was uninhabited before colonization. The island's contemporary population is based on migration, deportation, exile, and slavery. The majority speaks a distinct Creole. English and French are mainly used in administrative contexts and in school. Today, about 35,000 people live on the island. As many Rodriguans live on Mauritius, and about 10,000 have migrated to Australia.

Key challenges for the people living on Rodrigues include a lack of industrial development and, related to this, a high unemployment rate. The small island caters to tourism imaginaries of a place 'frozen in time' and 'unspoiled by development'. Reasons for this are (1) its geographical isolation about $560 \mathrm{~km}$ east of Mauritius; and (2) the cultural and economic neglect of its Creole population by a Hindu-dominated 'mother(is)land'. Creoles are traditionally considered under-represented within the Republic of Mauritius (Eriksen, 1998; Selvon, 2005). Politically, a Hindu majority dominates Mauritius, while the Franco-Mauritian minority owns most of the land (Eisenlohr, 2006; Mukonoweshuro, 1991). In the 1982 census, the term Creole was used to describe all those Mauritians who are descendants of African slaves. In the Republic of Mauritius, the Indo-Mauritians constitute $68 \%$ of the total population (and 52\% of Mauritians are Hindu); Creoles account for about 27\% of the population. In sharp contrast, Creoles make up around $97 \%$ of the residents of Rodrigues; and the same proportion upholds the Catholic faith there. These are two significant differences to the population of multiethnic Mauritius that have resulted in longstanding ethnic conflicts and a continued Malaise Créole (Boswell, 2006; Greig et al., 2011; Carroll \& Carroll, 2000a).

Poverty, especially within the Creole minority, threatens Mauritian social cohesion (Bunwaree \& Kasenally, 2007). The possibility of uprisings against the state authorities that might result from this was first highlighted by riots in 1999, after the death of the island's most popular Creole Seggae singer Kaya. Those presented the strongest case of civic violence since Mauritian independence (Laville, 2000). Compared to similar events elsewhere, these riots 
may appear of minor significance; yet, Mauritian authorities began to realize how fragile their peaceful 'rainbow nation' actually was (Carroll \& Carroll, 2000a; Miles, 1999; Bunwaree, 2002). This is especially critical for Mauritius as a tourist destination, where "Trouble in Paradise" would damage the island's widely touted reputation as a stable society and polity (Carroll \& Carroll, 2000b; AfDB-OECD, 2008). Yet, while social democracy and the welfare state remain part of Mauritius' political philosophy (Kasenally, 2011; Khoodabux, 2000; Bräutigam, 1997), inequalities and the economic effects of globalization continue to undermine the official discourse of a peaceful multiethnic society (Greig et al., 2011).

The ethnic conflict between Hindus and Creoles within the Republic of Mauritius becomes even more apparent in the case of Rodrigues. The great majority of Rodriguans see themselves in a disadvantaged position within the Republic of Mauritius because of their Creole descent, especially when it comes to important political decisions. Rodrigues has had limited access to decision-making processes. First under British rule, it was of no particular strategic or economic relevance to the colonizer. After Mauritian independence in 1968, its political dependency on Mauritius set it further apart, as efforts made by the political authorities for socio-economic improvement focused almost exclusively on the 'mother(is)land'. In both cases, this is partly due to the fact that Rodrigues is located in a remote location. The nearest international airport is on Mauritius, which is also the only destination for flights from Rodrigues. The closest harbour is Port Louis, also on Mauritius, roughly a 36-hour boat journey away. Consequently, all tourists (except for individual sailors that travel the Indian Ocean on their yachts) need to pass via Mauritius in order to reach the island.

The impact of the economic crisis of 2008 was compounded by the unique characteristics of the island's natural environment and the aforementioned considerable isolation from other countries, as well as ethnic differences that separate it from Mauritius. Apart from diverse employment opportunities related to the tourism sector, economic resources on Rodrigues are limited to fishing, agriculture and day-to-day businesses. Main incomes, apart from social benefits accruing from the Mauritian authorities, are generated through public sector jobs (especially civil service and education). Furthermore, today, there is a wide range of political and economic interests at play since Rodrigues received the official status of autonomy within the Republic of Mauritius in 2001. This gave the island's Chief Commissioner (CC) in agreement with his local government, the Rodrigues Regional Assembly (RRA), the right to spend money from a yearly budget allocated to him by Mauritian authorities.

Today, Rodriguans demand and depend on their share of tourism income generated in Mauritius. The following section provides an ethnography of how the economic crisis was tackled in a creative way by ATR and how its members put the negative image of a Creole minority suppressed by a Hindu majority into strategic use to gain support for their struggling tourism sector. This will account for ways in which local ethnic conflict continues to inform economics, politics and everyday practices in Mauritius. In doing so, the article adds a 'Rodriguan' layer to existing observations and argues that debates about ethnicity and political discrimination have not lost their importance in Mauritius; rather, their significance to concrete historic events where local elites find new ways and means to make use of them in support of their interests may need to be reconsidered. 


\section{Wergin}

\section{The ATR Experience}

My seven-month fieldwork on Rodrigues was focused on initiatives for the further development of the local tourism industry and its significance for Rodriguan culture and identity politics. I had visited the island before, in 2003. At the time, many of its inhabitants seemed enthusiastic about the prospect of turning Rodrigues into a new destination for what at that time had been identified as upcoming sustainable and eco-tourism (Williams, 2004). On my return, six years later, I expected to see some of the fruits of this promising plan. I was surprised, however, to note that not much had changed. A new tourism office had opened, and also a new hotel, Pointe Vénus. Conversely, another hotel had closed, and another ran out of business during my stay. The local tourism industry was obviously suffering from significant shortages in guest arrivals (see Table 1). In addition, the only airline assuring the connection between Mauritius and Rodrigues, Air Mauritius, had reduced its flights from up to six to two, sometimes only one, per day. As such, instead of tourism development triggered through the global interest in sustainable tourist destinations and islands 'unspoiled by development', the economic crisis of 2008 had become a serious threat to what until then had been a growing tourism sector, which now began to strongly affect the local economy, infrastructure and well being of the Rodriguan people as a whole.

Table 1: Tourist Arrivals on Rodrigues: 2004 - 2009

\begin{tabular}{|c|c|c|c|}
\hline & $\begin{array}{c}\text { Tourist } \\
\text { Totals }\end{array}$ & $\begin{array}{c}\text { Absolute } \\
\text { Change }\end{array}$ & $\begin{array}{c}\% \\
\text { Change }\end{array}$ \\
\hline 2004 & 48,068 & & \\
\hline 2005 & 41,442 & $-6,626$ & $-13.7 \%$ \\
\hline 2006 & 42,833 & 1,391 & $3.3 \%$ \\
\hline 2007 & 48,497 & 5,664 & $13.2 \%$ \\
\hline 2008 & 41,136 & $-7,361$ & $-15.2 \%$ \\
\hline 2009 & 40,350 & -786 & $-1.9 \%$ \\
\hline
\end{tabular}

(Source: RRA-Magazine 2010). ${ }^{2}$

As a response, local tourism entrepreneurs and associations, from hotel owners to dive instructors, formed Associations du Tourisme Réunies (ATR). Its name was deliberately chosen. The abbreviation ATR made reference to ATR 72, the plane used by Air Mauritius on the route between Rodrigues and its 'mother(is)land'; the very object through which the global economic crisis materialized itself on Rodrigues. ATR was founded as a reaction to the Rodriguan budget presented in early 2009, which did not (in the opinion of its members) foresee the appropriate measures to help the Rodriguan tourism industry regain its strength. Their initial idea was to convince the Mauritian government to deduct the fuel tax from the

\footnotetext{
${ }^{1}$ Upon googling the term "unspoiled by development", on 7 February 2012, five out of the first 10 results of an estimated 2,840,000 hits used this phrase to advertise tourist destinations.

${ }^{2}$ The significant drop in tourist arrivals between 2004 and 2005 is largely related to the outbreak of Chikungunya on Réunion Island, Mauritius and Rodrigues. This is an insect-borne virus transmitted to humans by mosquitoes. Tourists were worried that they might be infected with this virus whose symptoms are similar to dengue fever.
} 
cost of ticket sales for flights to and from Rodrigues. The resulting significant decrease in ticket prices was meant to boost the local tourism industry. If Mauritian authorities would not accept the necessary changes to the budget proposal that would be asked for by the Rodrigues Regional Assembly (RRA), the deputies of the RRA were asked not to accept the proposal either. Two further requests for support were sent out by ATR, one to the Prime Minister of Mauritius Navin Ramgoolam, the other to the then leader of the opposition party on Rodrigues, Organisation Du People Rodriguais (OPR), Serge Clair.

The members of ATR were not satisfied by the response of the Mauritian authorities to their request. On offer was a token deduction of the state fuel tax by 150 MUR (about US\$6) per ticket between Mauritius and Rodrigues, a return trip that cost about 8,000 MUR (US\$320) at the time. A further request of ATR to meet the Prime Minister personally was not answered. Even worse, ATR found that the Mauritian authorities, rather than using their suggestion to introduce promotional prices on airfares to help Rodrigues, had implemented a very similar scheme to increase tourism between Réunion Island (a neighbouring French overseas department) and Mauritius, leaving Rodrigues even more marginalized.

My first meeting with ATR was after these initial events, on a rainy day in early June 2009. The group had invited the public via local newspaper to join them at the Senior Citizen Centre of Mt. Lubin, a village in the heart of Rodrigues. This was where I met their main spokesperson for the first time, Aurele André, a charismatic, politically involved Rodriguan, who had already begun to use local and national media, newspaper, radio, and the Internet to draw attention to the economic situation on the island. On that day, he was forced to leave early because of other commitments as president of the Rodrigues Rotary Club. André was also the director of the François Leguat Giant Tortoise and Cave Reserve, which had opened in 2007 to reintroduce around 3,000 turtles to the island, and also to re-grow parts of its endemic forest on the reserve's 18-hectare estate. As such, he was a particularly influential figure on the small island, where important decisions for its political, economical and societal development lie in the hands of only a few people.

There were about 20 persons at the meeting in Mt. Lubin, mainly entrepreneurs in the tourism sector and trade union representatives who discussed how to take their interests further. The most important decision that day was to organize a demonstration in the capital of Rodrigues, Port Mathurin, within the next couple of weeks to draw more attention to their problems. The other spokesperson of the group who I met that day was Maxy André. He was the president of the Association des Gites et Table d'Hôte. I visited him a few days later in his house for a personal interview. During our conversation, he received a phone call from the Prime Minister's office and was told that Ramgoolam was to declare the upcoming demonstration a "non-event". From his point of view, their appeal should not be directed towards the Mauritian government but their Regional Assembly, and in particular its then Chief Commissioner (CC) Johnson Roussety.

The demonstration finally took place on 13 June and was a great success. Numerous people told me that it saw the largest crowd ever mobilized on the island. The first issue of the Mauritian magazine Week-End after the demonstrations on Rodrigues showed on its title page a large photo of the demonstrators carrying a banner that read, Maurice: To Bizin Konsider 


\section{Wergin}

Rodrigues ("Mauritius, you have to care for Rodrigues"), and the headline, Rodrigues: Le Cri Du Cour ("Rodrigues, the cry from the heart"). Of course, the organizers of ATR were satisfied. They met afterwards in the restaurant Chez Ram, whose owner invited everybody for dinner and drinks. This time, it was a smaller group that participated, made up of the same people that a few weeks later would travel to Mauritius for negotiations. During dinner, some were called on their mobile phones by different radio stations to give interviews. Sitting together allowed them to coordinate their responses, which also gave a more sophisticated and unified appearance to ATR.

On 22 June, ATR met with the CC. He made it explicit that the crisis on Rodrigues was connected to their conflict-ridden relationship with Mauritius. Roussety's argument was that the financial constraints that were put on the Rodriguan budget prior to its application made it impossible to ask for additional funds, even in a time of crisis. He pointed out that the problem was more fundamental than the price of airfares; but rather that the Mauritian government did not respect the autonomy of Rodrigues. Nevertheless, the fact that a ticket to Mumbai, Chennai, or Bangalore in India was at 15,000 MUR (US\$600), and a ticket to nearby Rodrigues cost 8,000 MUR (US\$320), was simply not justifiable. Meanwhile, Serge Clair, the then opposition leader, had decided to meet with Prime Minister Ramgoolam in Mauritius. This meeting was expected to have some positive impact; but it might also have given the Mauritian Prime Minister an opportunity to play Clair and Roussety against each other. When both fight over Rodrigues, Ramgoolam may have seen himself in a 'divide and rule' situation.

What seemed a business lobby in support of the local tourism industry, whose members were significant personalities within the social elite on Rodrigues, had by now turned into a broad political movement. ATR was partly made up of entrepreneurs who had supported Roussety and his promise of political change in the 2006 regional elections, after 25 years of OPR leadership. This support was now slowly fading. Similar changes were visible in regard to supporters of the OPR. Roussety's then party, the Mouvement Rodriguais (MR), interpreted the critical position that the OPR took towards what the Société Civil in the form of ATR could achieve as opposition to the movement. Even Rommel Farla, the union representative within ATR who was traditionally with the OPR, admitted that Clair's reputation had suffered from his apparent disinterest in their efforts.

Clair's plan was to wait until the $\mathrm{CC}$ had put himself into a dead-end situation, without further room to negotiate with the Mauritian authorities. Roussety had taken Mauritian authorities to the Supreme Court on the grounds that the autonomy status was breached because of the rejection to pay 10,000,000 MUR (US\$315,000) in compensation for Rodriguan fishers that were forced into early retirement. While the Mauritian Minister of Finance had urged the CC to withdraw his appeal, a decision on it was yet pending. This supported Clair's argument that only the OPR was able to govern Rodrigues effectively, based on a professional relationship with Mauritius.

However, things were to turn out differently. In their meeting after the demonstrations in the restaurant Chez Ram, ATR decided to use the now national attention given to Rodrigues and their cause to increase pressure on local authorities. Letters for all members of the RRA had already been drafted with the demand for a special meeting. It was on 22 June that the group 
met again, just before their meeting with the $\mathrm{CC}$, this time in the hotel Le Flamboyant. The RRA had decided to approach the Mauritian authorities one more time. The CC would send his Departmental Head, Pritam S. Mattan, who was also responsible for tourism affairs, to Mauritius. The ATR decided to field its own delegation to accompany him.

\section{Off to Mauritius}

I boarded the plane to Mauritius together with the ATR delegation on 5 July. It was the ATR 72 to which the group makes reference in its name, the only domestic plane that flew on the trajectory between Mauritius and Rodrigues, operated exclusively by Air Mauritius. A press conference was scheduled for Monday before the negotiation with government representative Ali Michael Mansoor, Financial Secretary to Prime Minister Ramgoolam. He was responsible for stopping the transaction of 10,000,000 MUR to Rodrigues to support the fishers' early retirement. He had already worked for the World Bank and, according to the expectations of the ATR members, he would be difficult to deal with.

The ATR delegation included Rommel Farla, who in his ordinary life drove a caterpillar and was the spokesperson for the Workers' Union on Rodrigues. Other members of the group were Marie Louise Augustin Roussety, president of the Organisation Femmes Entrepreneurs, James Begué, president of the Rodrigues Council of Social Services, McGill Meunier, a tourism entrepreneur, and Jean Pierre Lim Kin, president of the Association Rodriguaise pour un Développement Touristique Intégré. He had his own business, JP Excursions, with which he organized sightseeing trips for hotel guests and as such had a direct interest in an increase in visitor numbers on Rodrigues. While for him it would not matter whether those were domestic or international tourists, this was different for another member of the group, Willy Auguste, owner of Hotel Mourouk. It was the international tourists who booked hotel rooms and less the Mauritians who came to Rodrigues to buy spicy piment paste and dried fish and octopus, and often did not stay in hotels but preferred cheaper, self-catered apartments. For Auguste, the current situation of the negotiations with the Mauritian authorities was worsened by the fact that the offer made by the government was tied to the demand that hotels owners on Rodrigues, like him, would need to agree to a $25 \%$ discount on their accommodation rates, exclusive to Mauritian visitors. This demand had already been passed on to ATR, but its members were forced to keep it confidential. In light of upcoming elections, the Mauritian government itself wished to break the news to its citizens after contracts were signed.

During our stay on Mauritius we lived in Rose Hill, a city east of the capital Port Louis, in a guesthouse called Sunshine whose apartments were mainly used by regional and domestic tourists from Rodrigues, Mauritius and the Seychelles. Two rooms in each apartment, each with a double bed, a large living and dining area, toilet and shower in separate rooms and a fully equipped kitchen for 300 MUR (about US\$12) per person and night. The stay in shared budget apartments shows that the group came to Mauritius as visitors who had to pay for accommodation, transport and food, in contrast to government officials like Mattan, who lodged in a hotel paid for by the Mauritian authorities. Staying in Rose Hill, a large and poor workers' town about $20 \mathrm{~km}$ from the capital, and even further away from the beautiful sandy beaches and tourist resorts, emphasized the commitment of the participants to their project but 


\section{Wergin}

also the difficulties they were faced with. It also hinted that, while hotel and restaurant owners on Rodrigues were in support of the ATR cause, this was obviously not the case on Mauritius.

On the first day, Farla took me on a visit to his friend, a leading Syndicaliste who "had taught him everything"; how important it was to fight for one's rights and to create a forum through the work of unions. We spoke about his family who in his eyes was "really mixed". His father was French, his mother Malagasy. She always forbade him to play with whites because she would fear that they would seduce him to go to Europe, only to later kill him there. Twice, he had the chance to leave Rodrigues. One time, a French woman wanted to marry him. The other time, two French policemen saw him climb a steep ravine and wanted him to join the French mountaineers. But both times his mother said no.

Farla was the only member of the group who talked about the particularities of Rodrigues with me. One example was a story related to the fruits he would eat as a child when his family had nothing else. In the 1960s there were still many fruit trees and also much rice cultivation on Rodrigues so that no one actually had to suffer from hunger. But according to him, the English cut down those trees to make Rodriguans dependent on imports. On a similar note, he explained that the concept of buying something was not well established at the time within the local population. This allowed for Mauritians to take advantage of exchanges like rice against fish, or money against precious land. However, today Rodriguans were, in his opinion, better equipped, intellectually and politically, as shown by the intervention of their Société Civil in the guise of ATR.

Later that day, we met with Maxy André and Willy Auguste and spoke about the arrogance of the Rodriguan CC Johnson Roussety. With regards to the 10,000,000 MUR allocated to the fishers, he was to have said that this would make the Mauritian Prime Minister "drop his pants". It was such rumours that had made it difficult for Maxy and Willy to further support his government. They wanted to end the legacy of Serge Clair when they voted for Roussety. Still they expected more of him. But instead of change, there was talk about corruption, and that the $\mathrm{CC}$ had lost his temper too many times and ruined the relations with the Mauritian authorities, including Xavier Duval, Minister for Tourism at the time, who was known to like Rodrigues and its people, and to have a special interest in helping them.

According to Auguste, Duval would be happy to work more closely with tourism entrepreneurs from the island. When Ramgoolam was quoted that he does not want mass tourism on Rodrigues, this was apparently a statement made by Duval who knew about a possible sell-out of the island - of its most beautiful beaches and hotel spots to the highest bidder - under the Roussety government. Now the Mauritian government found itself in a similar position to these members of ATR. By supporting Roussety and his party, they wanted to oppose Clair who often blocked their promotion initiatives. But what they realized now was that Roussety was no better, in particular when for tourism promotion initiatives he sent his health secretary to South Africa to live in an expensive hotel; while Auguste, the tourism entrepreneur, joined him with one fourth of the budget available to him.

This was the political and social backdrop to the negotiations that would take place on Mauritius the following day. 


\section{Negotiations: Trumping the Ethnic Card}

Ali Michael Mansoor was Financial Secretary to Prime Minister Ramgoolam. According to Farla's friend, the Syndicaliste, he was the one with the real power in the country, with a monthly salary higher than that of Ramgoolam himself. He was a neoliberal businessman, and a key influence on the upcoming negotiations in which ATR was represented only by one of its members, Aurele André. He accompanied Mattan, the Departmental Head of Roussety, responsible for land rights and tourism development. According to André, the latter would have accepted the initial offer of 6,000 tickets, reduced by $30 \%$ from the standard fare, combined with a $30 \%$ reduction on Rodriguan hotel fares exclusive to Mauritians. But André refused. The fight for cheaper airfares had turned into a fight for Rodriguan Creole equality.

After the negotiations, André gave the following account of what had happened. When asked about his opinion towards subsidized tickets not only to but also from Rodrigues to the 'mother(is)land', Mansoor was to have said "Rodriguans? What do we want those on Mauritius for?" and furthermore that one had "dropped some bread" for the Rodriguans and it should be picked up. Based on these statements ATR reinvoked the sentiment of a neglected CreoleRodriguan people, oppressed by Mauritian politics and interests. After the news of the verbal assaults by Mansoor was spread to the other members of ATR, the group discussed what to do next. Marie Louise Roussety was particularly enraged ("en colère") after she was told about the incident. Old wounds became visible, and they were articulated. James Begué mentioned to me how he was treated in school. Every time he would have an answer to a question from the teacher, he would be called up with a particular voice: "Ahhh... le Rodriguais". Willy Auguste and Marie Louise could still hear this demeaning manner in which teachers would pronounce "Rodriguais" in their ears. Auguste even knew how to imitate the slur.

In a very short time, ATR generated a lot of support. Right after the negotiations, the group went to meet Father Jocelyn Grégoire, President of the Fédération Créole Mauritien (FCM), which he founded in 2007. In their meeting, he showed much understanding for the colere and promised to send a delegation to the press conference that was foreseen for the following day. From Father Grégoire the group continued for a meeting with the former President of Mauritius Cassam Uteem (see Figure 1). He was now a consultant for and representative of various national and international institutions, including the UN. The meeting could be arranged because Maxy André was a good friend of his late son. On the way, we heard on the radio that the unsuccessful negotiations were breaking news. We sat in his residence in a softly rosé room and spoke. Aurele André made every effort to explain the situation quietly and respectfully, even though he was obviously outraged and at the same time very thankful to be heard. Uteem was curious to know what I, as the only étranger, was doing in the group. He then gave André the advice to go public with Mansoor's behaviour.

The following day, ATR was invited to the headquarters of the opposition party Mouvement Militant Mauritien (MMM). A photo was taken of the ATR members sitting around a negotiation table that covered the front page of the 10 July 2009 edition of their party newspaper Le Militant. The situation had remained uncertain until that meeting. However, the Prime Minister had been heard on the radio saying with reference to the accusations made that a person who thought that the government has no consideration for Rodrigues "must be mad". 


\section{Wergin}

They would be doing everything they could to help Rodrigues but they also needed to make sure that money was spent properly.

Figure 1: The ATR delegation in front of Cassam Uteem's residence: (from left to right) Maxy André, Willy Auguste, James Begué, Aurele André, Cassam Uteem, Jean Pierre Lim Kin, Marie Louise Roussety, McGill Meunier, (the author), Rommel Farla. Photo: C. Wergin.

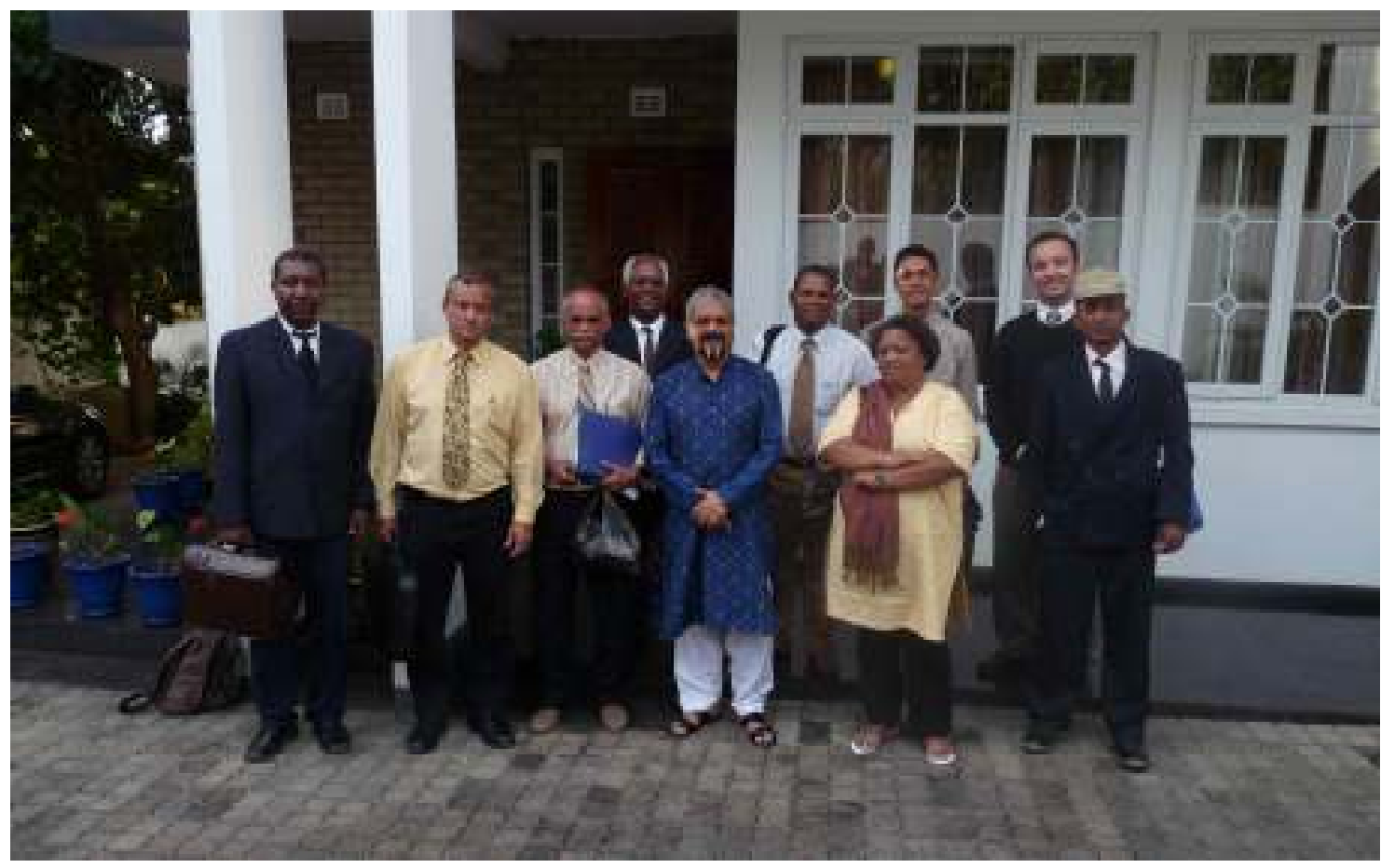

The same day, Rama Sithanen, the Deputy Prime Minister, Minister of Finance and Economic Development, personally called Aurele André, invited the Rodriguan delegation to continue negotiations, and promised that such an incident would not reoccur. In return, he demanded from ATR to publicly emphasize that their accusations were the result not of disrespect but of a simple misunderstanding. Within two days of Ramgoolam's statement, ATR returned to the negotiation table and a solution was found that was satisfying to all parties involved.

\section{Trouble in Paradise, Again}

What appeared to be a simple request for subsidized airfares turned into a considerable social, political and economic threat. When negotiations with government representatives ran the risk of failure, ATR 'trumped the ethnic card'. Threatening to go public with their accusations against Financial Secretary Mansoor, ATR created significant pressure on their opponents. On the one hand, there was a risk that these might provoke uprisings of the Creole population. Memories of the violent civil unrest in 1999 after the mysterious death of the Creole Seggae singer Kaya remain fresh (Vellien, 1999). On the other hand, the negative publicity of "trouble in paradise' could badly damage images of Mauritius as the 'rainbow nation' and a peaceful 
'multiethnic society', both of which are important marketing devices for tourist promotion and foreign direct investment on Mauritius.

The immanence of this threat was supported by fast information flows via informal networks, local media and the Internet. Facebook postings spread the word about conflict within minutes all over both islands. How individuals put related publicity manoeuvres into play becomes even more transparent and visible in a small island society. It was easy for me as an outsider to be accepted by ATR members and have privy to some (but not all) dealings. I can only speculate about why I was allowed to join them on their journey. One aspect might have been that, as researcher and academic, I was used as an apparently impartial witness to the events and negotiations that took place. Why they were so generous was related to their eagerness to share their version of the story and to have it documented. For that, they had found a good listener in me. The importance of this role became visible, for example, in the meeting with Cassam Uteem, despite the fact that I had no direct involvement in the actual negotiation process.

Personally, I was grateful for the opportunity to travel with ATR. After all, to be accepted and trusted by members of a local community is what any anthropologist hopes for. In that respect, my version of the events is not impartial but influenced by my close relationship with the group. Despite this admittedly subjective approach, the resulting ethnography allows for further conclusions about the small island community of Mauritius and its political system.

Ethnicity is a hot button topic and a political divisive one not only in Mauritius. Personal experiences and memories of segregation and mistreatment continue to inform perceptions and decisions. It is not surprising then that for some members of the delegation to Mauritius, it was a special experience to be part of ATR. They were working together strategically, driven by their interests as entrepreneurs but also by the group spirit and the united cause ATR represented, namely to defend Creole rights. Farla could not stop repeating how important it had been for him that they were there as one block and one voice; a large group that made a large impact on the people they were arguing with; the Mauritian tourism authority, Air Mauritius and government representatives. To my knowledge, no attempts were made to break this alliance, for example by the Mauritian government buying off one or two of its supporters. Even if such attempts were made, they did not succeed.

Other members of the group were less emotionally attached to the platform but acted more strategically. It was thanks to the many contacts of people like Maxy André that, after the initial unsuccessful negotiations, a large platform could be united, a platform of other Creole minorities, including Chagossians and FCM, of Syndicalists, and political parties. While in parts clumsy and even condescending, this platform showed that their ethnicity could provide leverage. It guaranteed significant pressure on the Mauritian authorities, who consequently needed to demonstrate more willingness to help the Rodriguan tourism sector. The government noted the possible danger of a nationwide outcry for Creole rights. After the failure of the first negotiations became public, numerous people began to proclaim the possibility of larger demonstrations. A country like Mauritius, that has an international reputation to lose in front of the eyes of UN, EU, industrial investors, and tourists, including attendants of the FIFA 2010 


\section{Wergin}

World Cup in South Africa, who had become an important marketing target, could simply not allow this to happen.

The impact of the agreement between ATR and the Mauritian authorities on the Rodriguan tourism sector is outlined in Table 1. Visitor numbers had been rising until 2007, a time when tourism was thought to become an even stronger economic player, and saw the opening of a new hotel on the island. Then, arrivals dropped significantly in 2008, the year of the global financial crisis. The program launched by ATR and the government helped stabilize arrival figures in 2009 (and 2010); a promotional offer that ran between August 2009 and December 2010 saw a reduction on airfares from 8,000 MUR (US\$320) to 5,430 MUR (US\$217), plus a $30 \%$ discount on accommodation for a minimum stay of four nights on the island.

\section{Discussion}

Official data to support the claims made by interviewees is limited to a few Mauritian newspaper articles. On 9 July 2009, L'Express printed a statement by Ramgoolam in which he emphasized that anyone who would think the Mauritian government would neglect Rodrigues would have "a serious problem". In an editorial of the same issue, the discussions between the Mauritian authorities, represented by Mansoor, and ATR were reviewed, suggesting that the problem was that "one does not understand the other". The government wanted to support the Rodriguan tourism sector while ATR aimed to bring the populations of the two islands closer together. While the former presented an economic problem, the latter's position was a largely political one. The above was a response to another article, printed in L'Express the day before, whose headline quoted Aurele André saying, "Financial Secretary Ali Mansoor has no heart." It outlined the negotiations that took place, reasons for their failure, and concluded with the announcement of a press conference held by ATR the following day, emphasizing that the issue might be taken to the streets of Port Louis where it would result in larger demonstrations.

Apart from the Mauritian papers, there are three local newspapers on Rodrigues. All of them covered the developments before and during the negotiation process. However, members of the MR own two of these papers and Serge Clair, leader of the OPR, founded the other. While all three claim journalistic integrity, their style of writing and argumentation (apart from the sports news) is often, if not always, aimed at discrediting the other party.

In relation to this, the main reason for me to keep the partly anecdotal character of the ethnographic description intact has been that it is the particular form of talking, of making claims, of gossiping and pretending to know more than the other about someone, their interests and whereabouts that strongly influences everyday action and political debate on Rodrigues. This la di la fé that is also common on Mauritius and Réunion Island (Wergin, 2010) - and I would argue in many other small island territories around the world - can bring about the fall of a regional politician and the rise of another. It is therefore not so much a question of whether claims are true or false, fact or fiction, but whether enough people believe in them.

While it has not been possible to 'solve' the financial crisis of the Rodriguan tourism sector by pressuring the Mauritian government, this case study of island-mainland politics in federated systems demonstrates how sensitive a small island state can be to an image of itself that serves 
as the basis for a whole industry and economy. One cannot advertise Mauritius if its government is said to undermine the rights of significant sections of its population. This and possible riots would cause tremendous damage to the aforementioned tourism imaginary of a peaceful, multiethnic 'rainbow nation' so carefully crafted in over 40 years of promotion activity. The case of Rodrigues shows how such tourism imaginaries, like the 'island paradise' that Mauritius is thought and marketed to be, need to be understood as complex sites of negotiation and contestation that demand careful diplomacy. Parallel examples are efforts made to redraft the imaginaries of Bali or Thailand as beautiful and apparently safe havens for tourism after what has become known as the 2002 and 2005 Bali bombings, and the Indian Ocean tsunami of 2004.

While ethnicity has been identified as a central commodity within tourist promotion (Comaroff \& Comaroff, 2009), imaginaries about ethnicity and peaceful 'multiethnic' togetherness are often far from the political and social realities of a place. Since members of ATR to a large extent represent the local business elite, their claims have great relevance; they are more widely heard and recognized than those of many other members of Rodriguan society. Their different enterprises are heavily dependent on tourism and as such they account for some of the main beneficiaries of their initiative themselves. The intervention of this local entrepreneurial elite in the decision-making process, and in regional politics in general, presents a new layer of accessibility to authorities, to power and political decision making beyond democratic means.

At the same time, the economic value that such imaginaries have for a tourist destination might stop a government from running certain risks, such as those associated with a public display of ethnic conflict, or whatever else might endanger the good standing and thus the open economy of the country. It appears that a growing Creole elite in Mauritius is well aware of its latent powers in this regard, and of the threats it can induce if it is to act as a unified opposition to its government. The 2008 UNESCO World Heritage listing of the Mauritian mountain Le Morne indicates further steps in the mainstreaming of Creole history in Mauritius: slaves throughout the 18th and early 19th century used this space as a hideout (UNESCO, 2012). It remains however to be seen if and how this largely 'negative heritage' of a neglected minority can be included in a more encompassing tourism imaginary for Mauritius.

Too many social and political factors played into the hands of the ATR negotiators. But the actual danger for Rodriguan development was not Mauritius, or an apparent reticence of the 'mother(is)land' to help. It was a Rodriguan society unable to produce political leadership that could work as a trustworthy partner in negotiations. The people that sponsored the political change in 2006 were the same entrepreneurs that now fought for help. Many of those who supported the MR back then only did so because the party seemed to offer a space for free expression, without judgement by an omnipresent leader. Most of them were interested in better living conditions, which for them were directly connected to economic well-being. What has become evident here is that both regional parties on Rodrigues, MR and OPR, need to take steps on how to incorporate a Société Civil into their political programs. OPR, especially its leader, has always considered itself to be the spokesperson for all Rodriguans. But many people on Rodrigues have by now enjoyed a level of education that allows them to speak for themselves, form their own opinions, and set up their own interest groups. They no longer simply listen to political leadership but know how to take action. 


\section{Wergin}

\section{Conclusion}

Based on an ethnographic study of the tensions between local and national decision makers, tourism entrepreneurs and politicians, this article has discussed how notions of ethnicity in conjunction with the 2008 global financial crisis can be put to creative use. In the case of Rodrigues Island's ATR versus the Mauritian authorities, the crisis reached well beyond economic development issues, right to the heart of an age-old ethnic conflict: the Malaise Créole within Mauritian society. Central to the analysis presented were the points of view of people directly engaged in and affected by political decision-making processes, ethnic difference and the global economic downturn. The article has presented the positive impacts of these people's innovative responses to this 'double-crisis', i.e. the development of new partnerships and collaborations, corporate social responsibility, and pointed at their creative use of information technologies and social media such as Facebook, all of which might lead to a more inclusive concept of a 'multiethnic Mauritian society'.

Tsing has criticized the imagery set up by globalization discourse and strategy at some length. She has shown that culture and politics of scale making are at the route of ideologies, wishes and fantasies about global economic interconnectivity, as well as political and social networking (Tsing, 2000). In contrast to ethnographic approaches that follow these forms of understanding and theorize the global as something complex but inevitable (Urry 2005), she has argued that "we need to study how scales, geographies, eras, and other imaginative terrains are differentially and dialogically negotiated, refused, or erased" (Tsing, 2000: 345).

It has been argued that tourism enlarges and transnationalizes the social spaces of host communities. When introduced as a new system of production and exchange, it modifies institutional frameworks. Within this new context of consumer-led economies, production becomes geared to the symbolic and aesthetic. Formerly irrelevant community practices can become relevant in this process, elevated to the status of symbolic resources that are mobilized to define and delimit local identity (Robinson \& Picard, 2006; Lash \& Urry, 1994).

There is however a need to go beyond this understanding of symbolism and aesthetics that focuses on tourism as a globalist concept; a touristification of the world. As an attempt to include the mobilization of people into the ideologies surrounding tourism, I have traced ATR's project as a particular historical event and followed its movements from demonstrations on Rodrigues to the negotiation table of the Mauritian government, via the rosé room of the house of a former President and the radio stations of the nation. This entangles the ATR initiative with local issues of translation and mobilization. It also moves the ethnographic discussion "into those cracks most neglected by unselfconscious reliance on global futurism, globalist conflation, and global circulation" (Tsing, 2000: 347). The concreteness of the ethnographic account connects mobility and mobilization; identities and interests are formed and travel as "place-transcending interactions" with open outcomes (ibid.: 350). The close reading of ATR's project changes the geographical and political perception of Mauritius, beyond its globalist self-understanding as a 'rainbow nation'. It proves to be a concrete historical episode with arguable repercussions in the future. 
On 5 February 2012, the Organisation Du People Rodriguais under the leadership of Serge Clair won the regional elections on Rodrigues and regained its leading political power on the island. This change has been foreshadowed by the events described above. It presents a new attempt of the Rodriguan people to establish a qualified political leadership that will work in their interests. Yet, this new attempt puts old political actors back into power so it remains to be seen whether OPR and its leader will acknowledge what their Société Civil is capable of and approach it differently from before.

\section{Acknowledgements}

All members of ATR are thanked for allowing the author insights into their work, sharing their stories and letting him accompany them on their journey. Thanks also to the Graduate School Society and Culture in Motion, Martin-Luther-University Halle-Wittenberg for granting the author the Postdoctoral Fellowship that made this research possible.

\section{References}

African Development Bank-OECD (2008) African Economic Outlook, meeting of Strategy and Policy Group, Issy-les-Moulineaux, France, 13-14 September 2007,

Aladin, I. (1993) Economic Miracle in the Indian Ocean: Can Mauritius Show the Way? Stanley, Republic of Mauritius, Editions de l'Océan Indien.

Boswell, R. (2006) Le Malaise Créole: Ethnic Identity in Mauritius, New York, Berghahn.

Bräutigam, D. (1997) 'Institutions, Economic Reform, and Democratic Consolidation in Mauritius', Comparative Politics, Vol. 30, No. 1, pp. 45-62.

Bunwaree, S. (2002) 'Economics, Conflicts and Interculturality in a Small Island State: The Case of Mauritius', Polis/RCPS/CPSR. Vol. 9, Special Issue, pp. 1-19.

Bunwaree, S. (2001) 'The Marginal in the Miracle: Human Capital in Mauritius', International Journal of Educational Development, Vol. 21, No. 2, pp. 257-271.

Bunwaree, S. \& Kasenally, R. (2007) 'Introduction' in S. Bunwaree \& R. Kasenally (eds.) Rights and Development: A Reader, Reduit, Mauritius, OSSREA, pp. 1-30.

Carroll, B.W. \& Carroll, T. (2000a) 'Accommodating Ethnic Diversity in a Modernizing Democratic State: Theory and Practice in the Case of Mauritius', Ethnic \& Racial Studies, Vol. 23, No. 1, pp. 120-142.

Carroll, B.W. \& Carroll, T. (2000b) 'Trouble in Paradise: Ethnic Conflict in Mauritius', Commonwealth \& Comparative Politics, Vol. 8, No. 2, pp. 25-50.

Comaroff, J. \& Comaroff, J. (2009) Ethnicity Inc, Chicago IL, University of Chicago Press.

Chatterjee, P. (2006) The Politics of the Governed, New York, Columbia University Press.

Dommen, E. \& Dommen, B. (1999) Mauritius: An Island of Success. A Retrospective Study 1960-1993, Oxford, James Currey.

Eisenlohr, P. (2006) Little India: Diaspora, Time, and Ethnolinguistic Belonging in Hindu Mauritius, Berkeley CA, University of California Press. 


\section{Wergin}

Eriksen, T.H. (1998) Common Denominators: Ethnicity, Nation-Building and Compromise in Mauritius, Oxford, Berg.

Eriksen, T.H. (1994) 'Nationalism, Mauritian Style: Cultural Identity and Ethnic Diversity', Comparative Studies in Society and History, Vol. 36, No. 3, pp. 549-574.

Greig, A., Turner. M. \& D’Arcy, P. (2011) 'The Fragility of Success: Repositioning Mauritian Development in the Twenty-First Century', Island Studies Journal, Vol. 6, No. 2, pp. 157-178.

Kasenally, R. (2011) 'Mauritius: Paradise Reconsidered', The Journal of Democracy, Vol. 22, No. 2, pp. 160-169.

Khoodabux, I. (2000) The Anatomy of Mauritius, Port Louis, Mauritius Printing Specialists.

Lash, S. \& Urry, J. (1994) Economies of Signs and Space, London, Sage.

Laville, R. (2000) 'The Politics of the Rainbow: Creoles and Civil Society in Mauritius', Journal of Contemporary African Studies, Vol. 18, No. 2, pp. 277-294.

Lincoln, D. (2006) 'Beyond the Plantation: Mauritius in the Global Division of Labour'. Journal of Modern African Studies, Vol. 44, No. 1, pp. 59-78.

Miles, W.F.S. (1999) 'Creole Malaise in Mauritius', African Affairs, No. 98, pp. 211-228.

Mukonoweshuro, E, (1991) Containing Political Instability in a Poly-Ethnic Society: The Case of Mauritius. Ethnic and Racial Studies, Vol. 14, No. 2, pp. 199-224.

Neveling, P. \& Wergin, C. (eds.) (2009) Re-Scaling the Anthropology of Tourism (Special Journal Dossier), Etnográfica, Vol. 13, No. 2, pp. 315-438.

Robinson, M. \& Picard, D. (2006) Tourism, Culture and Sustainable Development, UNESCO, Doc No CLT/CPD/CAD - 06/13.

RRA-Magazine (2010) Magazine of the Rodrigues Regional Assembly. April. www.gov.mu/portal/sites/rra portal/download/rramagazine/tourist.pdf

Selvon, S. (2005) A Comprehensive History of Mauritius, Port Louis, MDS.

Tsing, A. (2000) The Global Situation. Cultural Anthropology, Vol. 15, No. 3, pp. 327-360.

UNESCO (2012) Le Morne Cultural Landscape, http://whc.unesco.org/en/list/1259.

Urry, J. (2005) 'The Complexities of the Global', Theory, Culture \& Society, Vol. 22, No. 5, pp. 235-254.

Vellien, C. (1999) 'Rioting in Mauritius set off by Jail Death of Singer', The Guardian (UK), 25 February 1999, www.guardian.co.uk/world/1999/feb/25/7

Wergin, C. (2010) Kréol Blouz: Musikalische Inszenierungen von Identität und Kultur, Cologne, Böhlau.

Williams, S. (ed.) (2004) Tourism: Critical Concepts in the Social Sciences, London, Routledge. Wynne, B. (2005) 'Risk as Globalizing 'Democratic' Discourse? Framing Subjects and Citizens', in M. Leach, I. Scoones \& B. Wynne (eds.) Science \& Citizens: Globalization \& the Challenge of Engagement, London, Zed, pp. 66-82. 